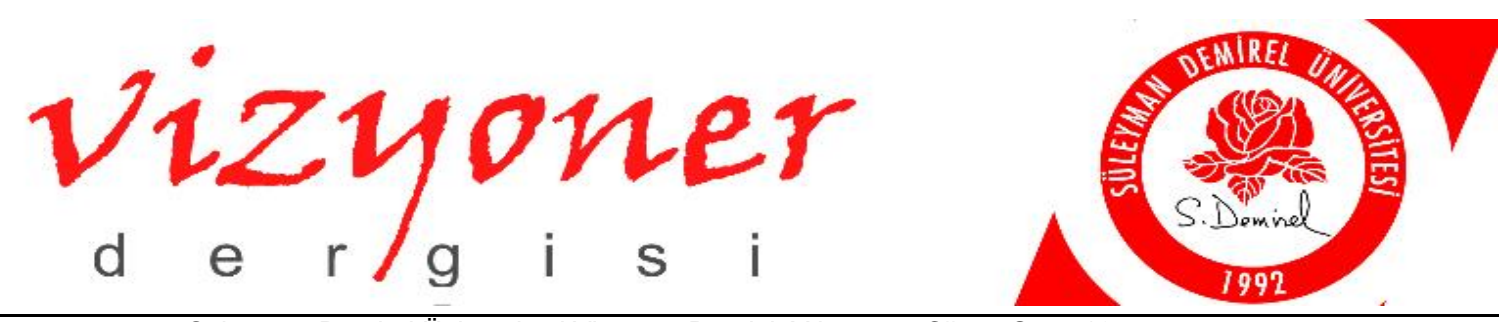

Süleyman Demirel Üniversitesi Vizyoner Dergisi, Yıl: 2016, Cilt: 7, Sayı: 16, ss.35-47. Suleyman Demirel University The Journal of Visionary, Year: 2016, Volume: 7, Number: 16, pp.35-47.

\title{
UZMANLAŞMA VE TIPTA BÜTÜNCÜL YAKLAŞIM ÜZERİNE BİR DEĞERLENDIRME
}

\section{AN EVALUATION ON THE SPECIALIZATION AND HOLISTIC APPROACH IN MEDICINE}

\author{
Yrd. Doç. Dr. Necla YILMAZ ${ }^{1}$ \\ Prof. Dr. Ramazan ERDEM ${ }^{2}$
}

\begin{abstract}
ÖZET
Endüstrileşme ile birlikte, ekonomik verimliliğin ve kitlesel üretimin artırılması amacıyla iş bölümüne gidilmesi, uzmanlaşmaya dayanan işlerin ortaya çıkmasına ve emek sürecinin değişmesine yol açmıştır. Bilgi birikiminin artmasıyla eski bütüncül dünya anlayışına sahip insan modeli yerini modern dönemin uzman insanına bırakmıştır. İş bölümü ve uzmanlaşmanın mesleklere yansıyan yönünde profesyonellik anlayışı gündeme gelmektedir. Yaşanan gelişmelerle birlikte tıp mesleğinde bölünmeler meydana gelmiş, modern tıp bilimsel uzmanlık alanların temel alan bir sisteme dönüşmüştür. Her bir alandan bir uzman hekimin sorumlu olduğu bu sistem, içinde bulunduğumuz yüzyılda uzmanlık alanlarının artışıyla kendini göstermektedir. Makro uzmanlık alanlarının mikro uzmanlık alanlarına doğru yöneldiği tıpta uzmanlaşma konusu, tıbbi ve sosyolojik manada incelenmesi gereken önemli bir olgudur.
\end{abstract}

Anahtar Kelimeler: Uzmanlaşma, Bütüncül Yaklaşım, Tıpta Uzmanlaşma, Sağlık Sosyolojisi.

JEL Sinıflandırma Kodları: I2.

\begin{abstract}
Resorting to division of labor for improving economic efficiency and mass production accompanying industrialization has led to the occurrence of specialization-based labor and change in labor process. The human model which has the old holistic cognizance has yielded to the expert person of the modern era with an increase of information accumulation. Professionalism cognizance comes to the agenda for division of labor and the reflection of specialization on occupations. Divisions have occurred in medical profession as parallel to the experienced developments, and modern medicine has turned into a system based on scientific specialization fields. A specialist physician from each field is responsible in this system and it is revealed with the increase of specialization fields in this century. Macro specialization fields gravitate towards micro specialization fields in medicine and specialization matter is a crucial phenomenon that needs to be examined in terms of medicine and sociology.
\end{abstract}

Keywords: Specialization, Holistic Approach, Specialization in Medicine, Medical Sociology.

JEL Classification Codes: I2.

\section{GíRiş}

Düşüncenin eşsizliği, geniş bir alan kapsamasından ve genelliğinden ileri gelmektedir. Bilginin ve bilimlerin çeşitli alt disiplinlere bölünmesi ve uzmanlaşmasıyla karakterize edilen içinde bulunduğumuz çağ (Capra, 1996:

\footnotetext{
Bu çalışma Süleyman Demirel Üniversitesi Bilimsel Araştırma Projeleri Koordinasyon Birimi tarafından 3800-D1-13 nolu proje ile desteklenen "Tıpta Uzmanlaşma Üzerine Nitel Bir Araştırma” isimli doktora tezinden üretilmiştir.

1 Süleyman Demirel Üniversitesi, İktisadi ve İdari Bilimler Fakültesi, Sağlık Yönetimi Bölümü, necla_bardak@ hotmail.com

2 Süleyman Demirel Üniversitesi, İktisadi ve İdari Bilimler Fakültesi, Sağlık Yönetimi Bölümü, raerdem@yahoo.com
} 
81); her şeyin parçalandığı, uzmanlaşmanın alıp başını gittiği bir metafora benzetilir (Schopenhauer, 2014: 34). Geçmişten günümüze akıl almaz bir hızla ilerleyerek, devasa hacimlere ulaşan bilgi birikimi ile baş edemeyen insanlık; mesleki ve kişisel tercihler sonucu bölünen bilgi alanlarıyla karşı karşıyadır.

Uzmanlaşma ve tıpta uzmanlaşma konuları, yalnızca tıp mesleğini icra edenlerin araştırma alanına hapsedilmeyecek kadar mühimdir. İbn Haldun'un tarihçiliği "külli bir ilim” (Timur, 2011: 41) olarak görmesine istinaden tıp bilimi de bir bütünlük içinde farklı meslek dallarına mensup kişilerce incelenip, değerlendirilebilir. Felsefecilerin görüşlerini, tıbbi sorunları analiz edip, değerlendirirken kullanmak yönetim zihniyeti ve insan bedeni arasındaki sistematik yaklaşımı örneklendirmektedir. $\mathrm{Bu}$ tarz konuların geliştirilmesi eleştirel değerlendirilmelerle başlar (Turner, 2011: 9). Tıbbın uygulamalı bir sosyoloji türü olması, tıbbi problemlerin sosyolojik teoriyi sürekli olarak insan biyolojisi, fizyolojisi ve sosyo-kültürel olgular arasındaki ilişkiyi sorgulamaya iter. Hattâ Foucault'ya göre 'modern tıp gerçekte uygulamalı sosyoloji ve sosyoloji de uygulamalı tıptır’ Turner (2011: 14). Böylesi konuları incelemek, çağın gerektirdiği önemli ve derin meselelere tartışma alanı açmak, ayrıca nedensel analizleri ile ortaya koymak gerekir. Bir meslek grubuna ait meseleleri gün ışı ğına çıkarmak için bazı kavram ve olgulara dair nesnel ve öznel gerçekleri de tartışmak gerekmektedir.

Uzmanlaşmaya ilişkin eleştirel yaklaşımlar yalnızca yazından ibaret kalmış, herhangi bir kuramsal yaklaşım ortaya konmamıştır. Yazarların düşünsel yaklaşımları ise, daha çok iş bölümü ve uzmanlaşmanın insanı yadsıyan ciheti üzerine yapılmıştır. Böylelikle 'uzmanlaşma' konusunun kendi bütünselliği içinde ele alındığı söylenebilir.

Adam Smith'in görüşlerinin aksine Karl Marx uzmanlaşmayı eleştirerek; bir ve aynı aleti hayat boyu kullanmanın verdiği uzmanlığın yerini, bir ve aynı makineye yaşam boyu hizmet etmenin verdiği uzmanlığın almasını konu edinir. Marx’a göre, makine, işçiyi çocukluğundan itibaren âdete makinenin bir parçasıymışçasına amacı dışında kullanmaktadır. Ayrıca, el zanaatları ile manüfaktürde işçi aleti kullanırken, fabrikalaşma sonucu makinenin işçiyi kullandığını söyler. Kısacası; işçi emek araçları tarafından kullanılmaktadır (Marx, 2003: 365 366). Bu noktada Jean-Baptiste Say'in şu sözlerine kulak vermek gerekmektedir; "İş̧̧inin yaşamı boyunca yalnızca bir toplu iğnenin on sekiz parçasından birini yapmış olduğunu görmek çok acıdır. Ama yalnız tüm yaşamını bir törpü ve bir çekiçle geçiren işçinin bu yüzden doğal niteliklerinin yozlaşacağı sanılmasın; en yüksek zihinsel yetenekleri benzer biçimde kullanan adam da bu durumdadır" (Durkheim, 2006: 68). Dönemin tek tip işini yapan insanı; saatlerce montaj hattında durup, yürüyen bantlar aracılığıyla önüne gelen arabanın belirli bir vidasını binlerce kez sıkmakla yükümlü olup başka herhangi bir şey yapmaya hattâ yanında çalışan arkadaşıyla bile sohbet etmeye vakit bulamayan robottan farksız bir haldedir. Böylesi bir çalışma ortamında makineye ve makinenin hızına göre çalışmak zorunda olan bu işçinin makineli üretimle birlikte "makineleşmiş" durumda olması kaçınılmazdır (Dikmen, 2011: 37). Böylelikle, endüstriyel devrimin sonuçları ortaya konulmuş; aşırı uzmanlaşma bireyi ve çalışma gruplarını, gerçeğin bütünlüğünden uzaklaştırarak, onların sistem ve yaşam üzerindeki denetimini giderek azaltmıştır. Bir iş bütün olarak bir kişi yahut birbiriyle iletişimi olan grup tarafından gerçekleştirilememektedir. Keza, endüstriyel devrim öncesinde bir elbise büyük ölçüde bir terzinin ve çırağının elinde sonuçlandırılırken günümüzde bu sürecin tamamına vâkıf olan ancak birkaç kişi bulunabilmektedir. Overlok, ütü, makas, makine, düğme ve fermuar işiyle uğraşan kişi sayısı fazladır lakin bir elbisenin tamamının bilgisine sahip çok az kişi kalmıştır (Demir, 2014: 55). Artık ayakkabı fabrikasında çalışan işçiler ayakkabıcı değildir. Bu işçilerin bir ayakkabıyı baştan sona yapma becerileri bulunmamaktadır. Bu kişiler basitleştirilmiş iş süreçlerinde, sürekli kendini yineleyen bir işi yapan vasıfsız elemanlar niteliğindedirler ve yaptıkları işi öğrenmeleri kunduracı çırağının öğrenme süresinden/sürecinden yüzlerce kat daha kısadır (Dikmen, 2011: 26). Endüstri döneminde yeni bir işçi sınıfının ortaya çıkmasıyla birlikte, üretimde maksimum kâr hedefleniyordu ve hedefe giden yolda sanayi işçilerinin, her türlü kullanımının mübah sayıldığı bir sistem oluşturulmuştu. Fabrikalaşma tek tip üretimi meydana getirmiş, her gün aynı işi yapmakla görevli işçi üretimin sonucunda ortaya çıkacak üründen bihaber, bütünsellikten uzaklaştırılmış bir vaziyetteydi. Smith bu verimkârlığın sebebini iş bölümü ve uzmanlaşmaya bağlarken, Marx iş bölümü ve uzmanlaşmanın insanı tek tipleştirdiğini, nihai ürün ve çevresindekilere yabancılaştırdığını savunur. İş bölümü sonucunda uzmanlaşmayı ve tabiî olarak uzman kavramını doğuran bu kapitalist sistem, uzmanlaşmamış insanın; işe, olaylara ve insanlara bütüncül olarak bakabileceğini de göstermektedir.

İnsan günlük hayatın rutin işlerine daldığında olup biten üzerinde durup düşünmez; bireysel olandaki sosyal olanı, tikel olandaki genel olanı göremez (Bauman, 2013: 19). Hattâ ünlü fizikçi Niels Bohr’a atfedilen sözlerde, uzman kişinin çalışma alanının kapsam yönüyle darlığı ve sınırlılığından ötürü hata yapma olasılığının yüksek olmasından bahsedilmektedir. Uzmanın çalışma alanı hakkında her şeyi bilme ve yorum yapma durumu değil, bildiği ve yorum yaptığı şeylerin doğru olmasına dikkat etmesi gerekmektedir. Zira sınırlı bilgi ve bakış açısıyla 
fikir yürütme ya da düşünme kişiyi genel bilgiye hâkim olma yetisinden yoksun bırakarak hata yapma durumunu tetikler, cehle neden olabilir.

Demir'e (2014: 61) göre günümüz araştırmalarının bir sonucu, bir kısım insanın sübjektif akıl yoluyla elde ettiği bilgilerin tüm zaman ve mekânlar için doğru olduğu inancının yanlış olabileceği görüşüdür. Yazara göre, uzmanların doğrusunun mutlak doğru olabilme olasılığı ise, büsbütün azdır. Uzman incelediği parçanın evrenin tamamı olduğu yanılsaması içindedir ki uzmanı olduğu alan yalnızca bir parçadan ibarettir aslında. Doğal dünyayı onu oluşturan parçaların daha detaylı incelenmesiyle en iyi anlaşılabilecek bir makineler dizisi olarak gören indirgemeci ve mekanik perspektif, miyop oluşturmaktadır. Karmaşık bütünü incelemek yerine, bütünü karmaşık olamayan en küçük birime kadar parçalayarak incelemeyi öngören Kartezyen yaklaşımda bütünü oluşturan bağlantılar ve ilişkiler görülmemektedir. Descartes'e göre, çözümlemeli düşünce süreci yani bir şeyi en küçük parçalarına ayırmak mutlak bilgiye götürecektir. Tıbbi doktrinde akıl ile bedenin ayrı birer varlık olarak görülmesi, maddî âlemin maddî olmayan âlemden ayrılmasının altında yatan sebepler arasındadır. Dolayısıyla tıbbın ve bilimin disiplinleri fiziksel olarak fark edilebilenin araştırılmasına dönüştü, görülemeyense başka disiplinlerin alanı oldu. Böylece modern tıbbın gelişimiyle birlikte, Kartezyen yaklaşım tıp alanı başta olmak üzere diğer alanlarda da kabul görmeye başlamıştır (Achterberg, 2009: 133).

Kartezyen düşüncesinin temelinde bakım ve şifacılığın birbirinden ayrılması yatar. İnsanın makine olarak algılanması, insanı denetleyen ve anlayan şifacılığın insancıllıktan uzaklaşmasına sebep olur. Geçmiş dönemlerin en gelişmiş teknik aleti saat olduğundan, 'saat gibi çalışan evren' şeklinde bir metafor oluştu. Dahası bu metafor insanlara indirgenerek, insanların da saat gibi parçalara ayrılarak incelenebilecek ve böylece anlaşılabileceklerdi. İnsanın bu tarz bir çözümlenmesiyle başlatılan süreçte, Batı tıp bilimi sürekli bir gelişim sağlamıştır. Günümüzde ise, sağlık ve hastalığı anlamada araç olan moleküler biyolojiye yani insan hayatının keşfedilmiş en küçük birimine bel bağlanmıştır (Achterberg, 2009: 134). İnsanın makine olarak algılanması, bio-iktidar (Foucault, 2011) felsefesinin bir devamı haline gelerek, insan bedeni-özne ikilisinden bedenin özneden müstakil bir hâl almasına sebep olmuştur. Durum böyle olunca 'beden hastalanınca makine bozulur' anlayışı doğarak bedeni tamir görevi hekime atfedilmiştir.

İnsanının teknolojiden, performanstan, emekten, paradan, meta değerinden, ilaçtan daha değerli görüldüğü; dâhili olunan sistemde teferruat değil bizzat özne olduğu bir dünyada hayal etmek doğal bir haktır. Modernleşme ile her bir şey münferit olarak değerlendirilirken, âlemdeki tüm olgular ayrı ayrı yani birbirinden bağımsız maddeler olarak ele alınmaktadır. Modern tıbbın uzmanlaşma derecesinin artmasıyla, tıbbın bütünlüğü üst uzmanlaşmalar, yan dallar şeklinde bölünme yaşarken, tıbbın varlığına sebep hastalar da bu bölünmeden nasibini 'hasta yoktur, hastalık vardır' sözünün tezahürü ile almaktadırlar. Hastayı yalnızca 'hastalar yığını' olarak gören bir anlayış, tıbbın insancıl yönünü nasıl yansıtabileceği tartışmalı bir konudur. Hastalıkların teşhisinde yaşanan gecikmeler, hastalığı yalnızca uzmanlık alanı açısından incelemeler, hekimler arası konsültasyon ve koordinasyon eksikliği hasta açısından menfi bir durumdur. Böyle bir durumun hekim yararına da olmadığ katidir, lâkin tıp sisteminin günah keçisi olma durumu bunun üstünü örtmemektedir. Capra’ya (2012: 184) göre, vücudun belirli bir parçasıyla belirli bir rahatsızlık arasında bağlantı kurarak oluşturulan konsültasyon iş̧leyişi, modern tıbbın indirgemeci yaklaşımına yenik düşmüş olabilir. Uzmanlaşmış disiplinler, doktorların hastalıkları organizmanın tamamını ilgilendiren bir bozukluk olarak göremeyip ona göre bir tedavi şekli geliştirdikleri bir noktadadır. Sözü edilen hekimler, yalnızca bir organ ya da bir dokuyu tedavi ederken, hastanın psiko- sosyal yönlerinin göz ardı ederek yani bedenin geri kalan kısmını dikkate almaksızın müdahalede bulunurlar. Bu şekilde parçalara bölünmüş (fragmantasyon) tıbbi müdahaleler amaçlarına ulaşsalar dahi haklı çıkma ihtimalleri düşüktür. Kapsamlı bir bakış açısı geliştirilmediği müddetçe, acıyı geçici olarak dindiren her şey zorunlu olarak iyi değildir.

Çalışma kapsamında; 'uzmanlaşma' kavramı ve uzmanlaşmanın karşısına aksi bir tez olarak sunulan 'bütüncül yaklaşım’ konusu kapsamlı bir şekilde ele alınmıştır. Ayrıca araştırmada; bütüncül tıp yaklaşımı çerçevesinde hekim, hastalar ve sağlık sisteminin değerlendirilmesi yapılmıştır. 
Süleyman Demirel Üniversitesi Vizyoner Dergisi, Yıl: 2016, Cilt: 7, Sayı: 16, ss.35-47.

Suleyman Demirel University The Journal of Visionary, Year: 2016, Volume: 7, Number: 16, pp.35-47.

\title{
2. SOSYOLOJIKK BİR KAVRAM OLARAK UZMANLAŞMA
}

\author{
"Uzmanlaştıkları konular dışında bu bilim insanları pencere pervazına yapışmış eşekarıları kadar \\ çaresizdirler... tek kelimeyle, bu kişiler zekâdan yoksun [without being intelligent] yalnızca malumat \\ sahibidirler."*
}

Uzmanlaşma olgusunu anlamaya ve açıklamaya yönelik olarak öncelikli ele alınması gereken konu, 'uzman' kavramı üzerine yapılmış yaklaşımların değerlendirilmesi üzerinedir. 'Uzman', herkesin sahip olmadığı bilgiyi elinde tutan ve bu bilgi sayesinde belli başlı durumlara karşı ayrıcalık elde eden kişidir. Kendisinin belirlediği ya da normlarla belirlenen uğraş alanında, bilgi hiyerarşisinin en üst basamağında yer alır. "Profesyonel", "ehil", “eksper”, “mütehassıs”, “erbap”, "bilirkişi” kavramları da “uzman” yerine kullanılmaktadır.

Her şeyin tek bir kişi tarafından bilinip uygulanması, bilimin ve bürokrasinin yavaşlamasına neden oluyordu. Aksine işlerin taksim edilerek belli başlı konularda ihtisaslaşılması gereklilik arz etmekteydi. Zamanla 'uzman daha az şey hakkında gitgide daha çok şey bilen, sonunda da hiç hakkında her şeyi bilen adamdır' şeklindeki deyimin kullanımı yaygınlaştı. Bu açıdan uzman kişi daha çok konuya hâkim olmak yerine, bir konuyu derinlemesine her yönüyle bilmeye çabalıyordu (Cündioğlu, 2010: 40-41). Shanteau'ya (1992) göre, uzman kişinin özellikleri arasında; ilgi alanına dair kapsamlı ve güncel olmak kaydıyla konunun içerik bilgisine sahip olmak, konuya dair alg1 yetenekleri gelişmiş olmak, karmaşık meseleleri basitleştirerek görebilmek ve karar alırken kendine güvenmek gibi unsurlar yer alır. Pörksen (2011: 93) ise, uzman kişinin bilirkişi olduğunu söyler ve onun görüşlerinin otorite sayılabileceğinin altını çizer. Her ne kadar kısmi yetki alanına sahip olsa da ilgili alanın tamamında yalnızca kendisinin yetkili olduğunu hissettirir. Uzmanlar ayrıca, teorik bilginin pratiğe aktarılmasında aracı ve arabuluculuk görevi üstlenerek realiteyi üreten konuma sahiptirler.

İnsan eylemlerinin temelinde yatan farklılıkların kaynağı sorgulandığında, bu eylemlerin sınıflandırılmasının belli başlı eylem türleri üzerinde çalışan, bir konuyu enine boyuna etraflıca araştırdıktan sonra görüş sunan, ilgilendiği konuya dair yol göstermeye ve tavsiyede bulunmaya yalnızca kendisinin hakkı olduğu iddiasında bulunan, bilgili ve güvenilir bir grup çalışan (ki bu kişi uzman olarak adlandırılıyor) profili ortaya çıkıyor (Bauman, 2013: 13). Bu kişiler politika, ekonomi, matematik, siyaset, edebiyat ve astronomi gibi çeşitli alanların spesifik bir kısmı üzerine yaptıkları sınıflandırmalarıyla bilinirler ve kendilerini o alanlarda söz sahibi kılarlar. Bauman'a (2014: 275) göre uzman, hem kişiye ait bilgilerin edinilmesinde güvenilir bir kaynak hem de karşısındaki kişilerin duygu ve düşüncelerini anlama ve yorumlama yeteneğine sahip, nesnel ve öznel dünya arasında bir köprü vazifesi kurabilendir. Illich'e (1994: 15) göre ise uzmanlar, yeni bir fikir modeli oluşturabilme gücüne, neyin ihtiyaç olup neyin olmadığı konusunda hüküm ve karar verme yetkisine sahiptirler. Ayrıca toplumu yönlendirme konusunda güçlü yeteneklerle donanmışlardır. Örneğin, eğitimciler topluma nelerin öğrenilmesi gerektiğini söylerler. Okul dışında öğrenilenlerin ise, işe yaramadığını söyleyerek topluma bunu kabul ettirebilecek konumdadırlar. Kurdukları bu tekel ile insanlarda bir gangster algı mekanizması oluştururlar (Gansgter algıdan kasıt, bireyleri en ufak bir alışverişte bile uzmanların önderliğinden yoksun bir şekilde hareket ettirmeme konusunda gerçek bir gangster edasında hareket etme meselesidir). Hattâ eski devirlerde yaşayan profesyoneller iş üzerinde kontrolü sağlamak (gücü korumak) için İstanköy adasında yaşayan doktorların mesleki sırlarını kendi çocuklarından başkasına öğretmeyeceklerine dair yemin ettikleri bilinmektedir.

Toplumsal açıdan bakıldığında, profesyonel bir tasarım sonucu olagelen ihtiyaçlar parçalara ayrılmış ve her bir parça ayrı bir uzmanın ihtisas alanı içine sokulmuştur (Illich, 1994: 24). Günümüzde uzman desteğine başvurulması gereken konuların sayısı ise bir hayli fazladır. "Uzman görüşü almak lâzım", "alanında uzman", "konusunda uzman”, "her bilginin uzmanı”, “işin uzmanına danışmak”, "uzman görüşüne göre”, "ilgili uzmanlar", "bir kardiyolog olarak benim görüşüm” şeklindeki kullanımların oldukça yaygın olduğu ve modern dünyada algılarımızın bu tarz kalıplarla şekillendirildiği söylenebilir. Bu bağlamda Turner’ın (2011: 242) uzmanlaşmayı bir 'güç ve statü artışı' olarak ele alması, toplumun uzmanlık konularıyla kesişme noktasını gösterir niteliktedir.

Giddens'a (2000) göre, geleneksel toplumda insana atfedilen 'evrensel insan' profili, modern topluma geçişle birlikte yerini 'uzman insan' profiline bırakmıştır. Debord (2006) ise, entelektüelden uzmana dönüşen profesyonellerin varlığından söz etmektedir. Yüksek bir uzmanlık düzeyi, entelektüelin toplumu bir bütün olarak kavrayıp ele alma kabiliyetini zayıflatacak şekilde bilginin gittikçe daha parçalı bir hal almasını teşvik etmektedir. Bu minvalde yazan Eyerman, "piyasanın gücünün, kültürel üretimin içeriğini belirleyici bir zorlama

Joad, C. E. M., (1947; Akt. Nalbantoğlu, 2011). 
yarattı̆̆gı"na işaret etmektedir (Furedi, 2014: 62). Uzmanlaşmanın artışı, entelektüellerin büyük resme bakmaktan caydırıldıkları ve kendi uzmanlık alanlarıyla ilgili anlamların peşinden gitmelerinin özendirildiği bir kültürden beslenmektedir. Tartışmalar giderek kendine gönderme yapan ve belirli bir uzmanlık alanındaki insanları dışarıda bırakan tarzda tasarlanmaktadır. Bu tür koşullar altında; nesnel bilgi, teknik bir karaktere sahip gibi görünmektedir. Uzmanlar ve teknisyenler daha derin içgörülerin arayışında olanların yerine geçmişlerdir. Günümüzde ise, bilgi yerine mikro bilgiler geliştirme eğilimi geliştirme çabası vardır (Furedi, 2014: 97).

Modern toplumların karmaşık bir yapıya bürünmesi ve uzmanlaşma derecelerinin artması ile herhangi bir durum karşısında kişisel tavır almayan, olayları tarafsız ve objektif değerlendirebilen uzmanlara olan ihtiyacı artırmıştır. Eski kültürlü kişi tipinin yerini uzman kişi tipine bırakmasıyla uzmanlık bilgisinin muteberliği gündeme gelmiştir (Weber, 1993). Foucault, 20. yy’ın evrensel entelektüelinin bilimsel-rasyonel tekniklere dayanan mesleklerin ortaya çıkmasıyla birlikte, yerini özgül entelektüle bıraktığını belirtmektedir. Entelektüelin uzmana dönüşüm sürecinde, halka yol gösteren, bilgilendiren olmaktan ziyade halkın mühendisi haline gelerek; bilgilerini yalnızca insan davranışlarını yönetmek için kullanan ve mevcut sistemin süreklilik kazanması için uğraşan kişi haline gelmiştir. Bu sayede uzmanlar ile halk (sıradan insan) arasındaki uçurum derinleşmiş, uzmanlık bilgisi ile sıradan insanın bilgisizliği arasındaki mesafe uzmanın otoritesinin varlığına bağlanmıştır (Keskin, 2011: 133).

Tarihsel zaman seyrinde bilgi birikimindeki büyük artış ve bilgiye dair her şeyi bilme arzusu bilimlerin uzmanlaşması gibi üstesinden gelinemeyen bir sonuç doğurdu. Tümel bilim olan felsefenin özgün doğası kendisini korudu fakat doğa bilimi, matematik, tarih gibi çeşitli bilim dalları felsefeden tamamen bağımsız hale gelerek yeni isimler aldı (Adjukiewicz, 1994). Bir bilgin, eş zamanlı birden çok bilimle uğraşmak bir yana bir bilimi bile tümden incelemelerine katılamaz hale gelirken, araştırmalarının alanı belli birkaç ya da hattâ tek bir sorunla sınırlı kaldı. Bu arada bilimsel faaliyetler, eskiden hekimlik, papazlık, yargıçlık, askerlik gibi daha çok kazanç getiren başka kimi işlerle birlikte yapılırken günümüzde gitgide artık yalnız başına yapılan bir iş oldu (Durkheim, 2006: 64).

Sosyal bilimciler faaliyetlerini yürütmede ve karar almada politik profesyoneller olarak adlandırdıkları uzmanlardan yararlanmaktadırlar. Profesyonellik anlayışına katkı sağlaması açısından, tıp bilimi ile benzerlik kurulmuş, özellikle hekimlere ait terimlerden faydalanılmıştır. Ekonomik ve toplumsal sorunlar 'beden politikaları' argümanı çerçevesinde değerlendirilmiş ve farklı yönlerden hekim-hasta ilişkisi uzman-müşteri bağlamında ele alınmıştır. Profesyonel uzmanlar, doktorların hastalara koydukları teşhis ve onlara uyguladıkları tedavi yöntemleri ile benzer durumları kendi müşterilerine de sunmuşlardır (Keskin, 2011: 106). Vücudunun herhangi bir bölümünde bir rahatsızlık hisseden kişi, sağlık hizmeti ihtiyacı duyduğunda, hekimlere bu noktada güven ve inanç duyarak hastaneye başvurur. Giddens'a (2012a: 30-31) göre, uzmanlara başvuran kişilerin duydukları bu inanç ve güven, yalnızca o kişilerden (uzmanlardan) kaynaklı değil, söz konusu uzmanlık alanı ve sisteminden kaynaklı olabileceği belirtilir. Burada kastedilen uzmanlığın 'teknik bilgi'sinden ibarettir. Hastanın, uzmanlık sistemine duyduğu inancın, kişi bazında hekim, sistem bazında ise uzmanlık sisteminden kaynaklandığı düşünülmektedir.

Goffman'ın sahne önü ve sahne arkası kavramları arasındaki ayrımın denetimi, profesyonelliğin belki de profesyonelleşmenin mecbur bıraktığı uzmanlaşmanın mihenk noktasını oluşturmaktadır. Giddens (2012a), uzmanların yaptıklarını diğerlerinden saklama nedenini uzmanların sahip oldukları uzmanlık bilgilerinin yanlış yorumlama ve bu bilgileri göz ardı ederek yanlış yapma ihtimaline sahip olmaları olduğunu belirtir. Burada sahne önü ile kastedilen hekimlerin hastalar ile bir araya geldiği yer, sahne arkası ise, hekimlerin kendileriyle baş başa kaldıkları zihin dünyalarıdır. Buradaki net ayırım, kusursuz olmayan becerilerin ve insan yanılabilirliğinin etkilerinin azaltmanın bir aracı olarak davranışları göz önünde bulundurur. Eğer hastalar tedavi süreçleriyle ilgili tam bilgi sahibi olsalardı, muhtemelen sağlık görevlilerine güven düzeyi bu denli yüksek olmayacaktır. Buradaki büyük bir risk olasılığını Giddens (2012a: 114) şu şekilde açıklamaktadır: "Uzmanın kendi bilgi alanı açısından bir bilgisizlik alnının mevcudiyeti sıradan insanların inancını zayıflatabilir. Bu tür bir gizleyişin sokaktaki insan tarafından keşfedilmesinden çok daha zararlı olan şey ise, belirli bir tehlikeler kümesi uzantılarının ve bunlarla ilişkili risklerin uzmanlar tarafından da anlaşılamadığı durumlardır. Çünkü böyle bir durumda sorgulanacak olan yalnızca uzmanlık bilgisinin sınırları ya da eksiklikleri değil, uzmanlık düşüncesinin özünü tehlikeye atan bir yetersizliktir."

Toffler'in ünlü tezinde, tarihte ikinci dalga olarak belirttiği endüstrileşme dönemi, yoğun iş bölümü ve üretimde standardizasyona ve kitleselleşmeye sebep olarak uzmanlaşmayı derinleştirmiştir (Toffler, 1981: 70-79). Üçüncü dalga'da bilgi en yüksek kalitedeki gücün kaynağıdır. Bu dönem durağan her şeyi değişime zorlayarak kitlesel 
üretimi kişisel üretime, kitlesel pazarlamayı mikro pazarlamaya, büyük ulus şirket yapılarından farklı örgütlenme biçimlerine dönüştürmektedir. Hattâ bu dönem proleteryadan (kol emekçisi) 'cogniterya' (bilim/bilim emekçisi) yaratan, yeni bir emek gücünün varlığıyla anılacak bu grubu yaratan bir dönem olmayı mümkün kılmıştır (Toffler, 1992: 33-38). Belek (1999) ise 'cogniterya' kavramını, üretimde teknoloji, sermaye gibi unsurlar önemini yitirirken, üretimin en önemli bileşeni olarak bilginin ön plana çıkmasıyla açıklamaktadır. Bilgiye sahip çıkan bu yeni insan, hiçbir kuruma ve sermayeye mahkûm kalmayıp istediği şekilde çalışabilir. Bilgi çağında işçiyi kullanan sermayedar değil, aksine sermayedara kendi isteklerini telâkki ettirebilen, bilgiyi kafasında taşıyan işçidir, yani bu yeni ve farklı emek gücünün tanımladığı yapı 'cogniterya'dır.

Elbette ki uzmanlaşma süreci kültürel bağlamdan bağımsız açıklanamaz. Bu noktada bireylerin düşünme, anlama ve yorumlama biçimleri, bakış açıları, sosyolojik davranışları, düşünce kalıpları, psikolojik tahlilleri, kavram ve durumları açıklamada önemlidir. Zijderveld'e (2013: 25) göre içtimai hayat içerisinde kültür, siyasal ve ekonomik unsurlardan bağımsız düşünülemez hattâ kültürün mezkûr unsurların temelini oluşturduğu söylenebilir. Kültür; değerler, normlar ve anlamların yıllanmasıyla oluşan geleneğe aittir. Japon kültüründe çalışanların Batı'daki meslektaşlarının aksine çok daha az uzmanlaşmaları (Giddens, 2012), klasik batı yönetim kültürünün temsil edilmediğini gösterir. Bu açıdan, her kültürün çalışma disiplini, iş kültürü, mesleki anlayışı ve bu unsurların iş bölümünün işe ve insan üzerinde yansıttığı sonuçlar farklılık göstermektedir.

Bireyin doğa ve toplumla ilişkisi, uzmanlar ve uzmanlaşmayı besleyen teknoloji aracılığıyla yürütüldüğü zaman, yaşamın kontrolü söz konusu teknolojiyi yönetenlerin eline geçiyor. Dünyanın yeniden şekillenmesinde rol alan, dünyayı ifade eden, gözetleyen ve yeniden tasarlayan uzmanlarla doluyor. Artık bireyin çevresi uzmanların ürettiği teknikten oluyor (Bauman, 2014: 294-295). Böylece bireyin periferisinde yer alan uzmanlar sebebiyle uzmanlara olan güven ve gereksinimi artırırken diğerlerine olan inancı zayıflatıyor. Illich (1994) ise, içinde bulunulan çağı insanların problemlerine karşılık uzmanların çözümlerinin var olduğu bir durum olarak değerlendirir. Uzmanların bir yandan problemin ne olduğuna karar vermeleri, öte yandan kendi çözümlerinden gayrısına hayat hakkı tanımamaları, onlara, olağanüstü bir güç kazandırmakta, gayrısını köle durumuna düşürmektedir.

\begin{abstract}
"Bilimin temel niteliklerinden biri de uzmanlaşmadır. Bilim kendi çalışma süreçleri içerisinde de 'uzmanlaşmaktadır.' Bilimin etkinlikleri iyiden iyiye profesyonelleşmiş okullar, bölümlendirilmiş araştırma enstitüleri yoluyla yürütülmektedir. Dünyanın araştırma nesneleri olarak parçalanması ve her parçanın ayrı bir araştırma konusu olarak uzmanlaşması sağlanmıştır” (Heiddegger, 1977: 125; Akt. Dikmen, 2011: 203-204). Burada, belirli bir araştırma konusunun belirli bir parçasında uzmanlaşan ve bütün dünyayı bu parçadan ibaret sayan, fildişi kulesinden çoktan çıkmış, insanların arasında şatafatlı bir hayat özlemekte, şöhret ve para peşinde koşan bir akademisyen tipi kastedilmektedir (Dikmen, 2011: 204). Özellikle doğal ve toplumsal yaşamın bütünü hakkında değil de, sadece bir kısmı hakkında ileri seviyede uzmanlık kazandıran yükseköğretim kurumlarında bu hastalığa çok yoğun bir şekilde rastlanmaktadır (Demir, 2014: 58).
\end{abstract}

\title{
3. MIIKRODAN MAKROYA-PARÇADAN BÜTÜNE: BÜTÜNCÜL YAKLAȘIM
}

Platon: "Geometri bilmeyen buradan giremez."

Yalnızca matematik ve geometri alanı öğrencileri için değil, akademisinde eğitim gören tıp ve felsefe öğrencilerini de "Geometri bilmeyen buradan giremez." şeklinde bir uyarıyla karşılayan Platon, matematiğin felsefeye giriş niteliğinde bir amaç taşıdığını düşünmekte idi. Birçok alanın bilgisine vakıf olmaya dayanan bu felsefe, Thomas Henry Huxley’in "hepimiz dar bir alanda çok şey; geniş bir alanda bir şeyler bilmek durumundayız" sözünün tezahürünü vurgularken, sadece uzmanı olduğumuz alanın mahkûmu olarak kalınmaması, diğer tüm ilgili alanlar hakkında asgari düzeyde bilgi sahibi olunması gerektiğine dikkat çekmektedir.

16. yüzyılda bilimsel devrimin başlaması, Kopernik, Bacon ve Galileo gibi bilim insanları ile evrene yeni değerler atfeden bir anlayışın hâkim olmasına sebep olmuştur. Bu yüzyılda bilgi ve bilgiye erişilen yollar daha dogmatik, bilimin icrası gözlem, deney ve daha çok matematiğe dayanan ölçülebilir ve niceliksel yöntem ile yapılagelmiştir. 17. yüzyılda ise, evreni büyük ve kusursuz dev bir makine olarak gören, deterministik ve mekanistik özellikte olan bu makinenin işleyişinin yalnızca akıl tarafından keşfedilebileceği düşüncesine dayanan Newtoncu anlayış hâkimdi. Yine 18.yy'da kendisi de hekim olan Lâ Mettrie gerçekte var olanın yalnızca maddeden ibaret olduğunu öne sürdüğü -İnsan, Bir Makine (Man a Machine)- isimli çalışmasında; 
insanda ruhun varlığının gereksizliği, insan bedeninin bir tözden yani maddeden ibaret olduğu ve hayvanlar ile insanların benzer yapıdaki canlılar olduğuna dair görüşlerini dile getirmiştir. İnsanı tıpkı mekanik bir saat ile benzer kefeye koyan bu anlayış: "Insan öylesine karışık bir makinedir ki, onun hakkında kesin bir fikir edinmek ve dolayısıyla onu tanımlamak ilk başta imkânsız gibi görünür. Insan vücudu, zembereklerini kendi başına kuran bir makine olup sürekli hareketin canlı imgesidir." cümleleri ile izah edilmeye çalışılmıştır. 20. yy'a gelindiğinde, tüm bilim anlayışlarının her durumda kabul görülemeyeceğinin altı çizilmiştir. İzafiyet (görecelilik) teorisinin ortaya atılmasıyla birlikte, olaylara ve bilime daha bütüncül, organik ve indeterminist bakılmaya başlanmış, insanın da içinde ve aslında merkezinde olduğu parçalardan ziyade bütüne odaklanan bir bilim anlayışı egemen hale gelmiştir.

Yukarıda bahsedilen bütünsellik ile kuantum teorisinin parçaların bütüne ait bilgiyi içinde barındırdığ düşüncesi anlatılmak istenmektedir. Kuantum teorisyenlerinden Einstein, Bohr ve Heisenberg gözlemledikleri dünyanın çok sayıda bağımsız nesnelerden kurulu bir makine olarak değil daha çok bölünmez bir bütün içinde ilişkiler ağına sahip olduğunu düşünüyorlardı (Capra, 1996: 16). Bütüncül bilim paradigması 20. yy’ın yüzyılın başlarında kuantum fiziğindeki buluşlarla birlikte boy göstermiş ve farklı teoriler tarafından desteklenerek gelişmiştir. Bütüncül bilimin, pozitivist ve fenomenolojik paradigmaların iki parçalı mekanistik evren anlayışının dışında çok katlı ve iç içe geçmiş dinamik bir bütün şeklindeki evren algısına dayandığı bilinmektedir (Dikeçligil, 2010: 58). Fizikçi David Bohm'un dile getirdiği bir bütün içinde her bir öğenin 'içrel' niteliğinin (özeliği, doğası) öteki öğelerden ayrı ve bağımsız olan bir özellik olmadığını, bunun öteki öğelerle ilişkilerden ortaya çıkan bir nitelik olduğu (Örs, 1996; Akt. Şahinoğlu Pelin, 2000: 122), evrende var olan hiçbir şeyin bütünden ayrı düşünülemeyeceği fikri ile bütüncül bilim anlayışına açıklık getirildiği görülmektedir. Arıtan (2010), bütüncül evren tasarımından yola çıkarak; evrendeki her bir parçanın aynı bütüne ait olduğu, her bir parçanın evrenin bilgisini içinde taşıdığı ve tüm bilgilerin her an ve her yerde olduğu görüşünü savunmaktadır. Evrendeki her kesit evrenin bilgisine sahiptir keza her bir parçacık birbiriyle etkileşim ve ilişki içerisindedir. İnsan mikro evren kabul edilirse hem bütünün kendisi hem de o bütünün bir parçası olduğu söylenebilir.

Bütüncül yaklaşım Elmacı'ya (2013: 41) göre, ilişkilerin tümüne birden aynı zamanda bakabilmek, sistemi oluşturan parçaları ve parçaların ilişkilerini bütün olarak görebilmek, bir parçaya bir etki olduğunda diğer parçalardaki etkiyi görebilmek, bir parçaya sistemin bütününü ilgilendirecek bir müdahale sürecinde, yapılan müdahalenin hem sistemin bütününü hem de herhangi bir parçayı etkileme ihtimali olan etkenlerin göz önünde bulundurularak hareket edilmesidir. $\mathrm{Bu}$ düşünce, psikolojide köklü bir geleneğe sahiptir. Sosyolojide ise, özellikle Frankfurt Okulu eleştirel toplum kuramı toplumsal bütünlüğünü dikkate alarak, birbirinden bağımsız ögelerle bütün arasındaki diyalektik ilişkiye dikkat çekmektedir. Keza herhangi bir öğe tek başına anlamlandırılmak istendiğinde, yetersiz kalınmakta, hattâ bütünün bilgisine ihtiyaç duyulmaktadır (Mayring, 2011: 38). Bu yaklaşım evrendeki her şeyin aynı bütünün parçaları olduklarını açıklamaya yöneliktir. Alatlı'ya (2002; 2014) göre, bütüncül dünya görüşü, klasik fiziğe nispeten yeni fizik anlayışı, bütünü daha iyi anlaşılabilir kılmak ve sistemlerin doğasını anlamak için parçalara değil, bütüne bakılması gerektiğini savunurken, eğitim alanında aşırı uzmanlaşmaya karşı doktrinler-arası ilişkilerin gelişmesi gereğini vurgulayan Sistemler Teorisi'ni ortaya koymaktadır. Bu görüş, tıp alanında ise, ferdi hastalıkların değil, insan bedeninin bütününe eğilen alternatif tıbbın revaç bulmasını sağlamıştır.

Batıda bütüncül anlayışının temsilcilerinden Ilya Prigogine'in (2005), "Kaostan Düzene” isimli kitabının sunuşunda Alvin Toffler'den aldığı ifadeler ile şunları aktarmaktadır: "Bizim uygarlı̆̆ımızın en önemli başarılarından biri, bir şeyi olabildiğince ayrıntılı şekilde görebilmek, anlayabilmek, analiz edebilmek için her şeyi mümkün olan en küçük parçalara bölmesidir. Fakat bu başarının bir zafiyet noktası var, o da şu: O kadar çok parçaya bölüyoruz ki, sonra bu parçaların hangi bütünün parçası olduğunu bulamıyoruz" Toffler'in bu kinayeli ifadesi ile, modern dünyada parçalanan ve bir o kadar da bölünen bilgi, bakış açımız ve hattâ hayatımızı etkileyen çağın egemen gücü konumuna gelen uzmanlaşma eleştirilmektedir. Bu açıdan bakıldığında (Timur, 2014), uzmanlaşma tutkusu ile hareket edenlerin genel kuramları küçük görme konusu, J. Schumpeter'in yalnızca bir tane Marx’ın varlığına rağmen, "iktisatçı Marx" ve "sosyolog Marx"ın yanı sıra "peygamber Marx"1 inceleyerek eksikliklerini ortaya koymakla örneklendirmektedir. Kısacası; "uzmanlık" adı verilen çoğu anlamsız bilgiler yığını içinde "parçaları" eleştirmek, bütünü eleştirmekten çok daha kolay hale gelmiştir (Timur, 2014: 475-476).

Geleneksel dünyada "ilm-i küll” yani bütüncül bakış ile anlatılmak istenen; disiplinlere ayrılmayan, dünyayı bir bütün olarak kavramaya imkân veren küllî, bütüncül ilimdir. Modern sosyal bilimsel terminolojide "bütüncül” 
anlamında karşılık bulan "holistik" kavramı ise, "ilm-i küll”den biraz farklıdır. Modern dünyada, aşırı uzmanlaşma ve ilmî parçalanma sonucu karmaşık sosyal olguları tek sebepli açıklama eğilimi sonucunda "indirgemecilik" anlayışı doğmuştur. Buradan yola çıkarak Karl Marx'ın, insanlar arasında var olan sömürü olgusunu, sadece iktisadi sebeplere bağlayarak açıklaması örnek gösterilebilir. Hâlbuki klasik Aristotelyen bütüncül perspektifi benimseyen Max Weber gibi sosyal bilimciler, tek-sebepli açıklamalara, indirgemeciliğe karş1, sömürüye yol açan maddî ve manevî birçok sebebi dikkate almışlardır. Nihayetinde bu durum indirgemeciliğe karşı holistik yani bütüncül perspektif olarak tanımlanmaktadır (Gencer, 2012).

Tarihte 1800'lü yıllardan önce ilimler toplanarak bir araya getirilmiş, kısa bir zaman sonra da bu ilimler konu ve metotlarına göre ayrıştırılarak kendilerine has bir yapı kazanmaları sağlanmıştır. İlim dallarının farklılaşması ve her bir dalın kendi metodolojisini oluşturma süreci, yalnızca belli başlı bilgi alanlarının oluşmasıyla sınırlı kalmamış, bu bilgi alanları da kendi içerisinde sistematik bir biçimde ele alınarak farklı perspektiflerden tasniflendirilmişlerdir (Üçer, 2014: 65).

Platon, Apollonios, Arşimed, Batlamyus gibi ilim adamları yalnızca düşünme disiplinlerini değil, geriye kalan bütün disiplinlerin bilgisini dahi Pisagor'dan almışlardır (Ebû Süleyman es-Sicistânî, 1979). İbn Sina, İbn-i Rüşd, Farabi, Aristoteles gibi şahsiyetlerin yalnızca bir (b)ilim dalı değil, birden çok (b)ilim alanıyla ilgilendiği de bilinmektedir. Bu gerçeği Koyre (2000: 21), Aristoteles'in başta mantık olmak üzere fizik, gökbilim, metafizik, doğa bilimleri, ruh bilim, ahlâk ve siyaset gibi alanlarda fikir üretmesi ile örneklemektedir. Hattâ Dante, Aristoteles hakkında 'bilenlerin/öğretenlerin sultanı' olarak bahsetmektedir. Ayrıca Koyre (2000: 16), dönemin filozoflarının birbirlerini anlamak için yalnızca karşı tarafın dilini bilmenin yeterli olmadığı, aynı zamanda felsefe bilmelerinin de gerekli olduğu vurgusunu yapmaktadır.

Weber'in "artık hiç kimse, tam bir uzmanlaşmaya dayanmadan bilim alanında yetkin bir şeyler yaptı̆̆ından emin olamaz" şeklindeki ifadeleri, bilim dallarını uzmanlaşma faktörünü hesaba katarak değerlendirmek gerektiği manasına gelmekteydi. Burada kastedilen "uzmanlaşma” libido sciendi (bilgi egosu/bilme şehveti) dürtüsüyle olguların farklı yönlerini araştıran bilim adamlarının tespitinin aksine, kapitalist gelişmelerle doğan

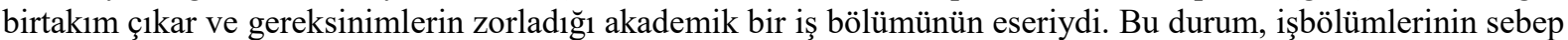
olduğu birbirinden bağımsız, kendilerine özgü dil ve kavramları olan ve birbirini anlamakta zorlanan bir sürü disiplinin ortaya çıkması ile sonuçlandı (Timur, 2014: 480).

Bazen bir dil başka bir dile çevrilirken salt ifadelerin değiştirilmesi, doğru anlam yüklenmediği takdirde bazı kelimelerin anlam kaybetmesine, çevrilen parçanın bütünlüğünün kaybedilmesine sebebiyet verebilir. Yapılan çeviri kelime bazına indirgendiğinde, ifadelerin parçalanmasından mülhem bütünlük anlam kaybeder ve parçanın özünden ve orijinalinden uzaklaşılmış olur. Bu konuya Pascal'ın fikirleri bir nevi ışık tutmaktadır (El Cisr, 2005: 153): "Duyu organlarımız bir şeyin gayesini bilmekten acizdir. Meselâ çok şiddetli bir ses kulağımızı sağır eder, hattâ patlatabilir. Normalin üstündeki sşık gözümüzü kamaştırır, belki kör eder. Bir şeye son derece yakın olmak onu görmemek demektir. Çok yakındaki cismi göremediğimiz gibi, çok uzaklaşınca da onu seçemeyiz. Hattâ böyle bir cisim bizim için yok gibidir." Demir'e (2012: 61) göre asıl tehlike, uzmanın aklının diğer akıllardan pek farklı olmaması ve üstünlük vehminin uzmanın aklını dumura uğratmış olmasındandır. Çünkü bir parçayı derinlemesine bilmek bütünün bilgisini vermemektedir. Parça bütünü oluşturmaz. Bütünü diğer parçalarla birlikte anlamamıza yardımcı olabilir. Parçayı görmek için ise, geri çekilmek gerekir. Çok derine inen uzmanın kuyudan çıkarılması ise zordur. Bu uzman, derinleştiği uzmanlık konusunu yeryüzünde yer alan tüm konulardan üstün ve yegâne görüp, diğer tüm konuları önemsizleştiren, yaptığı işi "son tarih uzmanı" şekliyle yansıtan, konusunda yer alan tüm kelimeleri dahi sahiplenerek, her birinin üzerine ayrı ayrı kafa yorup uzmancılık oynayan, bu alanda söz söyleme yetkisinin yalnızca kendisine ait olduğuna inan ve inandırmaya çalışan, sahip olduğu uzmanlık bilgisinin alanın bütününü kapsadığını zannetmektedir. İşini bitirdikten sonra geriye çekilip resmin bütününe bakan bir ressam misali, yıllar sonra uzmanlaştığı alana geriye çekilip bakan bir aydın, ancak bütünün bilgisini tam layıkıyla görebilir. İnsan derinlerde bütünü arayabilir ama bulamaz.

Mesnevi'de (Mevlana, Cilt III.) körlerin bir fili tarif etme hikâyesi anlatılmaktadır. Hikâyede, kör insanların çözmeye çalıştıkları hayvanın bir fil olduğunu bilemediği ve bütünü tarif etmede yetersiz kaldığı görülmektedir. Bu çıkarıma binaen, bütünün parçalardan oluştuğu ama yalnızca bu parçalardan ibaret olmadığı, parçaların bilgisine sahip olunarak bütünün bilgisine tam olarak ulaşılamayacağı, parçaların tek başına bir anlam ifade etmede yetersiz kaldığ 1 ancak bütün olarak bir anlam ifade ettiğinde amacın yerine getirildiği söylenebilir. Kısacası bütün, parçaların toplamına göre kayda değer derecede farklılık arz etmektedir. İlgili hikâye şu şekildedir: 


\begin{abstract}
"Hintliler karanlık bir ahıra bir fil getirip halka göstermek istediler. Hayvanı görmek için o kapkaranlık yere bir hayli adam topland. Fakat ahır o kadar karanlıtı ki gözle görmenin imkânı yoktu. O göz gözü görmeyecek kadar karanlık yerde file ellerini sürmeye başladılar. Birisin eline kulă̆l geçti, "Fil bir oluğa benzer" dedi. Başka birisinin eline ayă̆ geçmişti, dedi ki: "Fil bir direğe benzer." Bir başkası da sırtını ellemişti. "Fil bir taht gibidir" dedi. Herkes neresini elledi, nasıl sandlysa fili ona göre anlatmaya koyuldu. Onların sözleri, görüşleri yüzünden birbirine aykırı oldu. Birisi dal dedi, öbürü elif. Herkesin elinde bir mum olsaydı sözlerindeki aykırılık kalmazdl."
\end{abstract}

İktisadi alanda başlayan iş bölümü 1920'lerde sonra artan bir hızla insan bilimleri denilen bilim alanlarında da başat duruma geçmiştir. Bu durum, salt pozitif bilimlerde çalışan entelektüel için değil, sosyal bilimciler için de bir tür eleştirel bakıştan uzaklaşmayı anlatır. Bilimlerdeki iş bölümünün aşırılaşması, hayatı total bir değerlendirme bazında algılama şansını azaltmakta; mesleki deformasyon, entelektüel çalışmaların ve sistemin etkinlik tutkusu içinde hapsedilmesine neden olabilmektedir (Oskay, 2004: 226). Schiller, "İnsanın Estetik Eğitimi Üzerine Bir Dizi Mektuplar” isimli eserinde bilimlerde yaşanan ayrışma sonucu insanın içinde bulunduğu dünyayı şöyle özetlenmektedir: “Bir yanda zenginleşen deneyim ve daha kesinleşmiş bir düşünce, bilimlerin daha keskin ayrımı, öte yanda devletlerin daha karmaşık çarkları, sınıfların ve işlerin daha sert bir farklılaşmasını gerekli kılmasıyla birlikte, insan doğasının iç bütünlüğü de koptu; mahvedici bir kavga onun uyumlu güçlerini ikiye böldü... Bütünün yalnızca küçük bir parçasına ebedi olarak bağlanmış durumdaki insan da kendini parça olarak yetiştiriyor." (Schopenhauer, 2014: 12).

Durkheim, toplumun parçalardan oluştuğunu ve bu parçaları birbirlerine sıkı sıkıya bağlı olan kendi aralarında bütünleşmiş bir bünyeye benzetmektedir. Benzer şekilde, Giddens (2012: 145), vücut sisteminin beyin, kalp, akciğer ve karaciğer gibi uzmanlaşmış organlardan oluştuğunu ve bu parçaların (organların) birbirleriyle entegre bir halde çalıştığını, aksi bir durumda canlı varlığının tehlikeye girebileceğini söyler.

Parçaları bütünün içinde değerlendirebilme yeteneğine sahip kişiler, tek bir alanla ilgilenmezler. Birden fazla ilgi alanına sahiptirler. Bu durum onların olay ve olgulara sosyal, ekonomik ve psikolojik gibi farklı yönlerden bakmalarına imkân tanıyabilir. Cündioğlu (2010), 'düşünme' eylemine ve nesnelerin hakikatlerine ulaşabilme yolunda bütüncül bakabilmeyi şu cümlelerle anlatmaktadır: "Düşünme bütüne yöneliktir, salt görünür sebepleri değil, sebeplerin sebebini merak eder, görülemeyeni görmeye çalışır, tek tek ăgaçlarla değil, ormanladır onun işi. Ağaçları ormanın bütünü içinde görmeyi ister; ormanı görmedikçe ağaçları görmüş olmakla yetinmez, yetinemez. Adeta bir büyücü gibi, bir kâhin gibi hareket eder ve âlemi bir küre halinde önüne koyup o küreyi bir bütün halinde temaşa etmeye çalışır. Düşünmek, ă̆aca baktı̆̆ında tohumu, tohuma baktı̆̆ında ăgacı görmektir, hiç değilse bu türden bir görüşe ulaşmayı talep etmektir."

\title{
4. BÜTÜNCÜL TIP YAKLAŞIMI
}

Tıbbi çerçevede bütüncüllük; insan organizmasını tüm yönlerinin birbirine raptedilmiş ve birbirine muhtaç olması manasında düşünülebilir. Organizmanın doğal ve sosyal çevresiyle sürekli bir etkileşim içinde olduğunu kabul etmek anlamına da gelmektedir. Özellikle sağlık ve hastalık hallerinde ruh ve bedenin birbirlerine bağımlılı̆̆ını ifade eder (Capra, 1996: 192,198). Tıbbi araştırmaların organ yahut sistemsel bazda araştırma düzeyinden, hücre bazında araştırmalara ağırlık vermesi, insanı psiko-sosyal yönden ele alan bütüncül yaklaşımdan uzaklaşılmasına sebebiyet vermiştir.

Biyopsikososyal model, biyomedikal modelin eksik yanlarını tamamlamak üzere Engel (1980: 535) tarafından ortaya atılmış bütüncül ve bilimsel bir modeldir. Hekimlerin hastalara yaklaşımına ve sorun çözme yetenekleri üzerine odaklanan model ile tıbbın bütüncül ve insancıl yönü üzerine odaklanımaktadır. Kasapoğlu'na (2008: 15) göre model, hastanın biyolojik, sosyolojik ve psikolojik yönlerine odaklanarak bütüncül anlamda değerlendirilmesine izin vermektedir.

Bütüncül tıp anlayışı, kişilerin toplumsal ortamları içinde ele alındığı ve bu nedenle tıbbi algı ve anlayışa modern toplumlardaki rahatsızlıklar konusunda önemli bir katkı sağladığı varsayımına dayanır. Bütüncül tıp, hastaların kendi atmosferi içinde fiziksel bir varlık olduğu kadar, toplumsal, zihinsel, duygusal yönden bütüncül olarak ele aldığı tıbbi bir paradigmadır (Cockerham ve Ritchey: 1997). Örneğin; üroloji ve jinekoloji branşlarının birleşiminden ortaya çıkan ürojinekoloji yan dalı tıpta bir alt uzmanlık dalı olarak geçmektedir. Bu tür iki ayrı 
uzmanlık alanını da kapsayan yan dallarda olgulara geniş perspektiften bakmayı ve tedaviyi yürütürken hastayı bütün olarak görmeyi gerektirmektedir (Patel, 2011).

Bütüncül bilim anlayışı çerçevesinde hekimin hastasını parça-bütün ilişkisi açısından değerlendirip, hastaya herhangi bir teşhis koyarken ya da tedavi aşamasında onu bir bütün içinde ele alması gerekmektedir. Şahinoğlu Pelin'e (2000: 122) göre hastanın tanı koyma ve tedavi basamağında birbirini kapsayan bir şekilde yani bütüncül olarak ele alınışı iki şekilde olabilir. İlk aşama olarak hastanın tedavi edilmesi esnasında onun biyolojik bir sistem olarak bir bütün içinde görülmesi ve değerlendirilmesidir. Diğer aşama ise, onun biyolojik sistem olmasının ötesinde psikolojik ve sosyal bir varlık olduğu, tanı ve tedavi aşamalarında bunların onun biyolojik tedavisi kadar öneminin olduğunun bilinmesidir. Milz’e (1985; Akt. Mayring, 2011) göre; bütüncül tıp, her bir insanın kendine özgü bir bütüne (nev-i şahsına münhasır) ve kendine özgü bir ortama sahip olduğunu kabul eder ve bunu tedavinin temeli olarak görür.

Kişi bilimin belli bir alanında uzmanlaştığında, ilgili bilim dalına bütüncül olarak bakması kısmen de olsa engellenebilmektedir. Keza, hekimler de bir alan ya da bir organ üzerinde uzmanlaştıkları zaman dâhi hastayı bütüncül anlamda değerlendirmeden uzaklaşma ihtimalini taşımaktadırlar. Böylece hekimler hastaya ve hastalığa sadece kendi uzmanlık perspektifinden yaklaşacak, bakış açısında daralma söz konusu olabilecektir. Bu noktada hekimlerin 'uzmanlık' kaygısı taşımaları ve tıp eğitimine bakış açılarını yalnızca bir alanda uzmanlık kazanmakla sınırlandırmaları, alınan tıp eğitimi kalitesinin zayıflamasına sebep olduğu söylenebilir. Bu tarz durumlar hekimlerin hastalara değil hastalıklara odaklanmasına yol açarak, tıbbi bakım kalitesini sekteye uğratabilmektedir. Hastalar bu durumdan olumsuz anlamda etkilenebilirler.

Günümüzde neredeyse bütün bilim dallarının alt dalları uzmanlaşmadan nasibini almış ve uzmanlaştıkları alanın sınırlarına hapsolmuşlardır. Artık herkes kendi ilgi alanında söz sahibi olmaya başlamıştır. Kendi branşları dışına çıkmaya niyetlenenler ve belirli normları sorgulayanlar adeta yalnızca kendi çalışma alanları hakkında söz sahibi oldukları yanılgısına sürüklenmekteler. Mevcut sistemin içinde yer edinebilmek, sistemin sunucuları tarafindan şartlanmakta, konu kişinin ilgi alanında değilse, ilgi alanım ya da branşım değil şeklindeki baştan savmacı ve geçiştirmeci bir yöntemin kölesi durumuna gelmişlerdir. Aşırı uzmanlaşma ve spesifik branşlaşma, entelektüelliği kitaplardan ve dünyadaki yansımasından kaldırmak üzeredir. Az şey hakkında çok şey bilen insanlar, bütünü kavrama konusunda yetersiz kalmakta, bunu denemeye bile cesaret edememektedir. Bu durum kişinin ömrünü, teknik bilginin körleştirici zindanında geçirmesine sebep olmaktadır. İnsanın düşünce dünyası, disiplinleri birbirine bağlayan köprülere ihtiyaç duymaktadır. Bu anlamda körü körüne uzmanlaşmayı reddedenlerle, bütünleştirici köprüleri kurmaya çalışanlar anlaşılmaya çalışılmalıdır (Alican, 2010, 351-356).

Türkiye'de bütüncül yaklaşım Nusret Fişek tarafından hazırlanan '224 sayılı Sağlık Hizmetlerinin Sosyalleştirilmesi Yasası' ile toplum hekimliği çerçevesinde düzenlenmiş ve sağlık sisteminde birinci basamağa yerleştirilmeye çalışılmıştır. Birinci basamağı sağlık sisteminin merkezine yerleştiren ve sevk zincirini başlatan bu sistem Alma Ata konferansından çok önce birincil bakımın önemini vurgulamıştır (Güler ve Akın, 2012). Dünya'da ise, 1923 yılında ilk kez Francis Peabody tarafından sağlık hizmetlerinin bireysel sağlık hizmeti veren bir uzmanlık dalına olan gerekliliği ve hali hazırdaki bu eksikliği sağlayabilecek yapının aile hekimliği sistemi olduğu dile getirilmiştir. Tıp kurumunda görülen aşırı uzmanlaşmanın sağlık hizmeti alımı esnasında hastaların ortada kalmasına sebep olduğunu belirtmiştir (Türkiye Halk Sağlığı Kurumu).

"Tababet sanatı gittikçe iştigal sahaları çoğalan ilimlere dayanmak ve hekimler de umumi bilgilerini çok genişletmek mecburiyetindedir. Bu saha genişledikçe ihtisaslar ehemmiyet kazanmaya başlamıştır. Ve zamanımızda tıp tahsilini yenice bitiren bir hekimce ihtisas en mühim bir umde olmuştur. Evet bu yirminci asırda ilim hayatının bir ihtiyacıdır. İhtisasta yalnız ufak bir kısmın mütalaası ile iktifa etmek ve ihtisası birçok fasıllara ayırarak yalnız cüz'i bir kısmı ile uğraşmak çok defa görgüleri çok mahdud bir sahaya inhisar ettirmek tehlikesini ortaya koymuştur. Onun için kâfi derecede bütün şubelerde esaslı malûmat ve tecrübe sahibi olduktan sonra teferruatla işstigal etmenin en doğru bir yol olduğu kanaatine varılmuştır. Mütehassislar çoğalmakla beraber hakiki hekimlerin azalmamasını temin etmek lâzımdır. Tababetin yalnız bir istikamette yürümesinin böyle bir netice vermesinden korkulmalıdır." Ünver'in (1938: 2) dile getirdiği bu satırlar Türkiye'de Cumhuriyet'in ilk yıllarına münhasır bir ihtisaslaşma anlayışının olduğunu ve tıp açısından bu durumun oldukça ehemmiyet arz ettiğini belirtmiştir. Uzmanlaşmayı bir ihtiyaç olarak gören Ünver, tıbbi uygulamaların yalnızca bir alana indirgenmesinden doğabilecek muhtemel tehlikeye dikkat çekerek, genel hekimlik anlayışını kazandıktan sonra uzmanlaşılması gerektiğini vurgulamaktadır. Uzman hekimlerin çoğalmasıyla hakiki hekimlerin yani genel hekimlerin (hastaya bütüncül yaklaşan eski hekimler) sayısında bir azalma olabileceğini ve bu durumun tehlikesinin göz önünde bulundurulması gerektiğini belirtmektedir. 
Uzmanlaşma günümüzde modern tıbbın hastalıklara yaklaşımında önemli rol oynarken, teşhis ve tedavideki başarı oranını artırmaktadır. Hekimler çalışma alanlarını ne kadar daraltırlarsa, o alandaki birikimleri hayli artmakta ve tıbben daha yararlı olmaktadır. Tıbbın teşhis ve tedavi açısından geldiği nokta, tıpta uzmanlaşma sayesindedir (Uran, 2011). Fakat birçok araştırma düzenli hizmet kaynağının uzman hekim değil, birinci basamak hekimi olmasının hastaların hizmete erişimi, sağlık çıktıları, sadece gerekli tedavilerin uygulanması, sağlık hizmetinin maliyeti vb. değişkenler açısından çok daha başarılı sonuçlar verdiğini göstermiştir. Sistemsel olarak yapılan bu yorumun birinci basamakta görülen sağlık sorunlarının ikinci ve üçüncü basamakta görülen sorunlardan çok temel bazı farklılıklar göstermesine neden olmaktadır. Ayrıca sağlık hizmetlerinin her aşamasının kendine özgü sorunlara yanıt verebilecek özellikte sağlık çalışanları gerektirmesine bağlıdır. Birinci basamak sağlık hizmetleri, toplumda sık görülen, geniş bir yelpazeye yayılan, genellikle erken dönemde ele alınan ve koruyucu hizmet ağırlıklı sağlık sorunları ile ilgilenirken, ikinci ve üçüncü basamak hizmetlerinin ilgi alanına toplumda nadir görülen, çeşitlilik açısından dar bir tanı kapsamındaki, genellikle geç bir dönemde karşılaşılan ve tedavi ağırlıklı hizmete gereksinim duyan sağlık sorunları girer. Tüm bu sebeplerden ötürü birinci basamakta çalışan hekim hastalığa değil, sağlıklı bir insana bütüncül bir bakış açısıyla bakabilmeli, aynı zamanda sağlık hizmetinin farklı basamakları ile eşgüdüm sağlayabilmelidir (Öcek ve Vatansever, 2012: 54-55).

\section{SONUC}

Disiplinlerarası bilim anlayışına olan ihtiyacın giderek arttığı günümüzde, disiplinlerarasında yaşanan kopukluk, bilginin parçalanmışlığını gözler önüne sermektedir. Her bir disiplinin birbiriyle mutlak yoldan bağlantısının olması aslında bu parçalanmışlığa bir reddiye mahiyetindedir. Tıbbın kendi alt dalları arasında yaşadığı kopukluk ise, kimi zaman hekimlerde bir durağanlığa ve bilgilerini kullanmada tekdüzeliğe sebebiyet verebilirken, kimi zaman tıbbın hümanistik niteliklerini bastırarak yerini yozlaşmış değerlere bırakabilmektedir.

İnsanın bedenen ve ruhen bir 'bütün' (vücutta her bir hücrenin birbiriyle bağlantı içinde) olması, bir hastalığın teşhis ve tedavisinde göz önünde bulundurulması gereken en önemli hususlardan birisidir. Fakat hekim adayları tıbbi eğitim süresince hastayı hedeflediği uzmanlık dalı perspektifinden değerlendirmekte, yalnızca hekime başvurulan şikâyet çerçevesinde, diğer muhtemel faktörlerden uzak olarak ele almaktadır. Hekimler bu durumun bir sonucu olarak yalnızca kendi spesifik alanlarına yoğunlaşmakta, tıp fakültesinden mezun olduğu zaman aldığ 'tabip' sıfatına ters, 'uzman' unvanına uygun olan bir durumun içerisine girmekte, hekimlik yerine uzmanlık kimliğinin ön plana çıkmasına sebep olabilmektedirler. Dolayısıyla, bahsi geçen kısmi alanda uzmanlaşma ile teşhis ve tedavi sürelerinde gecikmeler yaşanabilmekte, hasta açısından zaman kaybı ve bedeli hayatla ödenebilecek muhtemel durumlar hattâ sağlık sistemi açısından sağlık hizmeti maliyetlerinin artması şeklinde sonuçlar doğabileceği şüphesi her zaman göz önünde bulundurulmalıdır.

\section{KAYNAKÇA}

Achterberg, J. (2009). “Kadın Şifacılar”, (Çev. B. Altınok), İstanbul: Everest Yayınları.

Adjukiewicz, K. (1994). "Felsefeye Giriş Temel Kavramlar ve Kuramlar”, (Çev. A. Cevizci), Ankara: Gündoğan Yayınları.

Alatlı, A. (2002). "Bütüncül Düşünce Devrimi”, http://www.alevalatli.com.tr/makale.asp?s=detay\&ID=38 (Erişim Tarihi: 19.11.2014).

Alican, M. (2010). "Kitap Tanıtım ve Değerlendirme: Tarih ve Psikanaliz, Bilim ile Kurgu Arasında", Tarih Okulu, Ocak-Nisan, Sayı VI, s. 251-256.

Arıtan, A. (2010). “Holistik Evren Tasarımı”, İstanbul: Arıtan Yayınevi.

Bauman, Z. (2013). “Sosyolojik Düşünmek”, (Çev. A. Yılmaz), İstanbul: Ayrıntı Yayınları.

Bauman, Z. (2014). “Modernlik ve Müphemlik”, (Çev. İ. Türkmen), İstanbul: Ayrıntı Yayınları.

Belek, İ. (1999). "Postkapitalist Paradigmalar”, İstanbul: Sorun Yayınları.

Capra, F. (1996). “Yeni Bir Düşünce”, (Çev. M. Armağan), İstanbul: İz Yayıncılık.

Capra, F. (2012). “Batı Düşüncesinde Dönüm Noktası”, (Çev. M. Armağan), İstanbul: İnsan Yayınları. 
Cockerham, W. C. and Ritchey, F. J. (1997). "Dictionary of Medical Sociology”, United States of America: Greenwood Press.

Cündioğlu, D. (2010). “Daire’ye Dair”, İstanbul: Kapı Yayınları.

Debord, G. (2006). “Gösteri Toplumu”, (Çev. A. Ekmekçi ve O. Taşkent), İstanbul: Ayrıntı Yayınları.

Demir, F. (2014). "Bulaşıcı Salaklık Epidemiyolojisine Giriş”, İstanbul: Phoenix Yayınevi.

Dikeçligil, B. (2010). "Bilimsel Paradigmaların Oluşumunda ve Dönüşümünde Sosyolojik Bağlam”, Toplum Bilimleri, Haziran, 1-3, s. 53-61.

Dikmen, A. A. (2011). “Makine İş Kapitalizm ve İnsan”, Ankara: Tan Yayınları.

Dünyada Aile Hekimliği, http://ailehekimligi.gov.tr/aile-hekimlii/duenyada-aile-hekimlii.html (Erişim Tarihi: 17.11.2014).

Durkheim, E. (2006). “Toplumsal İşbölümü” (Çev. Ö. Ozankaya), İstanbul: Cem Yayınevi.

Ebû Süleyman es-Sicistânî. (1979). "Müntehabu Sivâni'l-Hikme”, (Nşr. D. M. Dunlop), The Hague: Mouton Publishers.

El Cisr, A. N. (2005). “İlim-Felsefe-Kur’an Işığında İman”, (Çev. R. Barışık), İstanbul: Kitabevi Yayınları.

Elmac1, N. (2013). "Sağlık Antropolojisi: Diyarbakır Örnekleri”, Ankara: Siyasal Kitabevi.

Engel, G. L. (1980). "The Clinical Application of the Biopsychosocial Model, The American Journal of Psychiatry", 137: 5, May, p. 535-544.

Foucault, M. (2011). “Özne ve İktidar”, (Çev. O. Akınhay), İstanbul: Ayrıntı Yayınları.

Furedi, F. (2014). “Nereye Gitti Bu Entelektüeller?”, (Çev. A. E. Koca), Ankara: Atıf Yayınları.

Gencer, B. (2012). "Prof. Dr. Bedri Gencer: Modernleşme, Tarihi Hızlandırıyor”, http://yazarokur.blogspot.com.tr/2012/10/prof-dr-bedri-gencer-modernlesme-tarihi.html (Erişim Tarihi: 21.01.2015).

Giddens, A. (2000). “Siyaset, Sosyoloji ve Toplumsal Teori”, (Çev. T. Birkan), İstanbul: Metis Yayınları.

Giddens, A. (2012). “Sosyoloji”, (Çev. İ. Yılmaz), İstanbul: Kırmızı Yayınları.

Giddens, A. (2012a). “Modernliğin Sonuçları”, (Çev. E. Kuşdil), Ayrıntı Yayınları, İstanbul.

Güler, Ç, ve Akın, L. (2012). "Halk Sağlığı Temel Bilgiler”, Cilt III, Ankara: Hacettepe Yayınları.

Illich I. (1994). “Körelten Meslekler”, s.11-43, içinde Illich, I., I. K. Zola, J. McKnight, J. Caplan, H. Shaiken, (1994). "Profesyoneller İktidarı”, İstanbul: Pınar Yayınları.

Illich, I. (2011). “Sağlığın Gaspı”, (Çev. S. Sertabiboğlu), İstanbul: Ayrıntı Yayınları.

Kasapoğlu, A. (2008). "Madalyonun İki Yüzü: Hastalık ve Sağlık”, Ankara: Phoenix Yayınevi.

Keskin, F. (2011). “Politik Profesyoneller ve Uzmanlar”, Ankara: De Ki Basım Yayım.

Koyre, A. (2000). “Bilim Tarihi Yazıları”, (Çev. K. Dinçer), Ankara: Tübitak Yayınları.

Marx, K. (2013). “1844 El Yazmaları”, (Çev. M. Belge), İstanbul: Birikim Yayınları.

Mayring, P. (2011). "Nitel Sosyal Araştırmaya Giriş”, (Çev. A. Gümüş ve M. S. Durgun), 1. Baskı, Ankara: BilgeSu Yayınları.

Öcek, Z. ve Vatansever, K. (2012). "Uzmanlık Hizmeti Ağırlıklı Sağlık Sistemlerinin Toplum Sağlığı ve Sağlık Emek-Gücü Üzerindeki Etkilerine Yönelik bir Değerlendirme”, Diş hekimi Dergisi, Süreli Yayın, Ocak Sayısı, http://izdo.org/dosya/dergi/dishekimi-45-sayi.pdf (Erişim Tarihi: 03.08.2015).

Patel, A. (2011). "From Super-specialist to Generalist? The Way Forward, Journal of Mid-Life Health", Jan-Jun; 2(1), p. $1-2$

Pörksen, U. (2011). “Plastik Kelimeler”, İstanbul: Açılım Kitap. 
Prigogine, I. (2005). “Kaostan Düzene”, İstanbul: İz Yayıncılık.

Şahinoğlu Pelin, S. (2000). “Tıp Evrimi Açısından ve Psikiyatri Özelinde Konsültasyon Kurumu”, Klinik Psikiyatri, Sayı 3, s. 117-125.

Schopenhauer, A. (2014). “Okumak Yazmak ve Yaşamak Üzerine”, İstanbul: Şule Yayınları.

Şenol, M. (2010). “Keşfini Bekleyen İnsan”, Ankara: Kadim Yayınları.

Shanteau, J. (1992). "The Psychology of Experts: An Alternative View", in Wright, G., Bolger, F. (Ed.), Expertise and Decision Support, p. 11-23. New York: Plenum Press.

Toffler, A. (1981). “Üçüncü Dalga”, (Çev. A. Seden), İstanbul: Altın Kitaplar.

Turner, B. S. (2011). “Tıbbî Güç ve Toplumsal Bilgi”, (Çev. Ü. Tatlıcan), Bursa: Sentez Yayıncılık.

Üçer, İ. H. (2014). “El-Fihrist’te Felsefe Tarihi: Kadim’in Mukaddes’e Yolculuğu”, içinde Felsefe Tıp ve Tarih, M. Arıcı, (Ed.), Klasik Yayınları: İstanbul.

Ünver, A. S. (1938). “Tıb Tarihi”, İstanbul: Matbaai Ebüzziya.

Uran, B. (2011). “Tıptan Psikiyatri Uzmanlığı Kaldırılmalıdır”, http://www.derki.com/hekim/tiptan-psikiyatriuzmanligi-kaldirilmalidir (Erişim tarihi: 02.08.2015).

Weber, M. (1993). “Sosyoloji Yazıları”, (Çev. T. Parla), İstanbul: Hürriyet Vakfı Yayınları.

Zijderveld, A. C. (2013). “Kültür Sosyolojisi”, (Çev. K. Canatan), İstanbul: Açılım Kitap. 